\title{
MEMAHAMI FAKSIONALISME SEBAGAI UNSUR INHEREN BAGI DINAMIKA PARTAI POLITIK
}

\author{
Aprilianto Satria Pratama \\ Mahasiswa Program Studi S2 Politik dan Pemerintahan, Universitas Gadjah Mada Yogyakarta. \\ E-mail: aprilsatriapratama@mail.ugm.ac.id
}

\begin{abstract}
ABSTRAK. Tidak diundangnya Ganjar Pranowo ke acara resmi Partai Demokrasi Indonesia Perjuangan (PDIP) di Semarang, Jawa Tengah (Jateng), pada 22 Mei 2021 dan ilegalitas penyelenggaraan Kongres Luar Biasa Partai Demokrat di Deli Serdang (KLB-DS), Sumatera Utara, pada 5 Maret 2021 semakin mengukuhkan peran faksionalisme sebagai unit analisis yang inheren bagi kajian partai politik dan elektoral. Dengan mengajukan 'bagaimana faksionalisme muncul dan mempengaruhi partai politik' sebagai rumusan masalah, penelitian ini berupaya untuk menunjukkan proses kemunculan, cara kerja sekaligus konsekuensi-konsekuensi faksionalisme bagi partai politik. Penelitian ini meminjam kerangka berpikir V.O. Junior-Zariski dan metode penelitian studi kasus dengan literature review sebagai teknik pengambilan data dominan untuk mengungkap realitas yang terjadi. Penelitian ini lantas sampai pada beberapa temuan. Pertama, bahwa faksionalisme bisa diproduksi oleh aktor-aktor internal dan eksternal, meski awal mula konflik akan selalu berasal dari sumber internal. Kedua, meski faksionalisme lekat dengan nuansa konfliktual yang merugikan, namun demikian, ternyata faksionalisme juga memproduksi keuntungan. Ketiga, bahwa penyebab faksionalisme masih disorot secara lebih dominan dari sudut pandang konflik personal, bukan kegagalan institusional.
\end{abstract}

Kata kunci: faksionalisme; konflik; PDIP; Partai Demokrat

\section{UNDERSTANDING FACTIONALISM AS AN INHERENT ELEMENT TO POLITICAL PARTY DYNAMICS}

\begin{abstract}
The situation where Ganjar Pranowo was not invited to the official event of the Indonesian Democratic Party of Struggle (PDIP) in Semarang, Central Java (Central Java), on May 222021 and the illegality of holding the Extraordinary Democratic Party Congress in Deli Serdang (KLB-DS), North Sumatra, on March 52021 makes the role of factionalism as an inherent unit of analysis for the study of political and electoral parties stronger. By proposing 'how factionalism emerges and affects political parties' as a problem statement, this study attempts to show the process of emergence, the workings as well as the consequences of factionalism for political parties. This research borrows V.O. Junior-Zariski and case study research methods with literature review as the dominant data collection technique to reveal the reality that occurred. This research then arrived at several findings. First, that factionalism can be produced by internal and external actors, although the origin of conflict will always come from internal sources. Second, although factionalism is closely related to conflictual nuances that are detrimental, however, it turns out that factionalism also produces benefits. Third, factionalism are still highlighted more dominantly from the point of view of personal conflict, not institutional failure.
\end{abstract}

Keywords: factionalism, conflict, PDIP, Partai Demokrat

\section{PENDAHULUAN}

Ganjar Pranowo, saat penelitian ini dilakukan, adalah kader Partai Demokrasi Indonesia Perjuangan (PDIP) yang juga merupakan Gubernur Jawa Tengah (Jateng) sejak 2013. Otomatis, Ganjar akan selalu jadi orang pertama yang diundang oleh PDIP ketika partainya tersebut berkeperluan untuk menyelenggarakan acara internal di Jateng. Undangan tersebut, tentu saja, bukan hanya ditujukan kepada Ganjar dalam kapasitasnya sebagai perwakilan Pemerintah, melainkan juga dalam kapasitasnya sebagai kader internal PDIP. Namun demikian, menjelang berakhirnya bulan Mei 2021, publik terkejut setelah mengetahui bahwa Ganjar tidak hadir di acara resmi PDIP yang sedang diselenggarakan di Semarang, ibukota Jateng.

Mendengar informasi tersebut, publik, otomatis terkejut. Pertama, bagaimana mungkin acara resmi PDIP diselenggarakan di Jateng, bahkan di ibukotanya, tetapi Gubernurnya, yang merupakan kadernya sendiri, justru tidak diundang ketika semua anggota legislatif dan eksekutif dari PDIP di Jateng diundang? Kedua, bagaimana mungkin situasi tersebut terjadi pada PDIP, partai yang terlanjur diagungkan sebagai partai harmonis yang selama ini tidak pernah berkonflik? Ketiga, bagaimana mungkin Ganjar, yang selama ini selalu memberikan pernyataan-pernyataan yang menunjukkan loyalitasnya pada PDIP, menjadi tampak dimusuhi sedemikian rupa?

Namun demikian, belum sampai pertanyaanpertanyaan tersebut terjawab, beredar rundown di kalangan jurnalis yang menunjukkan secara eksplisit bahwa Ganjar memang tidak diperkenankan untuk menghadiri acara tersebut (Assifa, 2021). Rundown tersebut lantas menjadi artefak yang seolah memberi konfirmasi bahwa situasi yang terjadi memang telah direncanakan oleh pejabat tinggi partai. Akibatnya, pertanyaan publik kian mengerucut, konflik apa yang sedang terjadi antara Ganjar dan PDIP? 
Konsekuensinya, Puan Maharani, yang hadir menjadi pembicara utama pada acara tersebut, jadi dikait-kaitkan. Apalagi karena dalam pidatonya, Puan menggaris bawahi satu materi kepemimpinan krusial yang seolah menyindir Ganjar; "Pemimpin itu di lapangan, bukan di sosmed" (dmr/sur, 2021).

Bambang Wuryanto, ketua Dewan Perwakilan Daerah (DPD) PDIP Jateng yang bertanggung jawab terhadap penyelenggaraan acara lantas menjelaskan bahwa situasi tersebut erat kaitannya dengan Pemilihan Presiden (Pilpres) 2024. Menurutnya, Ganjar memang sengaja tidak diundang karena telah menunjukkan keinginan, meski tidak secara eksplisit, untuk menjadi kandidat Presiden dari PDIP pada Pilpres 2024 mendatang. Padahal, ketua umum PDIP, sebagaimana diketahui, bahkan belum membuat keputusan apapun perihal kandidasi untuk menghadapi Pilpres 2024 tersebut. Ganjar, dengan demikian, dianggap mendahului keputusan Megawati Soekarnoputri, ketua umum yang juga merupakan seorang figur sentral partai (Mustafa, 2011).

Menariknya, di sisi lain, boleh jadi keriuhan tersebut dipicu oleh dukungan publik yang justru datang secara generik kepada Ganjar. Faktanya, elektabilitas Ganjar di beberapa survey memang konsisten berada di lima besar (Damhuri, 2021). Bahkan, sudah ada pula partai di luar PDIP yang membuka opsi untuk mendukung Ganjar (Dinilhaq, 2021). Meski demikian, sudah menjadi rahasia umum bahwa PDIP ingin mengajukan Puan sebagai kandidat yang akan bertarung dalam Pilpres 2024. Bukan hanya karena Puan merupakan anak dari Megawati Soekarnoputri, ketua umum PDIP dan Presiden ke-5 Republik Indonesia (RI) dan cucu dari Soekarno, Presiden pertama RI, melainkan juga karena Puan merupakan komunikator politik yang ulung dalam membangun jaringan konstituen, saluran komunikasi dan strategi pesan (Triutomo, 2020). Konflik memperebutkan rekomendasi partai tersebutlah yang lantas memproduksi faksionalisme, yaitu faksi pendukung Ganjar di satu sisi dan faksi pendukung Puan di sisi lainnya. Memang, di luar kedua faksi tersebut, boleh jadi masih ada lainnya. Namun demikian, yang sedang muncul kepermukaan adalah kedua faksi tersebut. Faksionalisme, dengan demikian, mulai tampak perannya sebagai topik kajian yang secara konsisten mengiringi dinamika tumbuh kembang partai politik.

Secara praktikal, sebenarnya publik sudah memiliki pengalaman dalam memperbincangkan faksionalisme. Apalagi karena pada Februari-Maret 2021, sekitar tiga bulan sebelum konflik Ganjar dan PDIP mengemukan, masyarakat sudah terlebih dulu membicarakan faksionalisme yang terjadi pada Partai Demokrat. Meski demikian, berbeda dengan
Ganjar yang berhadap-hadapan dengan aktor-aktor internal, saat itu faksionalisme Partai Demokrat dibicarakan dalam cakupan yang lebih luas karena sampai melibatkan aktor-aktor eksternal.

Agus Harimurti Yudhoyono (AHY), ketua umum Partai Demokrat saat itu, bersitegang dengan kelompok yang tidak lagi menganggap sah kepemimpinannya (Prasojo et al., 2021). Belakangan, muncul fakta bahwa beberapa tokoh senior partai yang sudah dipecat seperti Jhoni Allen Marbun dan Darmizal, terlibat dalam proses kemunculan kelompok yang tidak lagi menganggap sah kepemimpinan AHY tersebut. Menariknya, meski sudah dipecat, mereka masih memiliki keberanian untuk menggelar Kongres Luar Biasa (KLB) Partai Demokrat di Deli Serdang, Sumatera Utara, pada 5 Maret 2021 (Wijaya, 2021). Adapun agenda utama dari KLB tersebut adalah memilih ketua umum.

Puncaknya, Moeldoko, yang saat tulisan ini disusun masih menjadi Kepala Kantor Staf Kepresidenan (KSP), didaulat oleh peserta kongres untuk menjadi ketua umum menggantikan AHY. Meski hanya melalui telepon genggam karena masih berada di Jakarta, Moeldoko lantas menerima amanat tersebut (detikcom, 2021). Keriuhan pun terjadi. Di ranah digital misalnya, keriuhan tersebut sampai memproduksi dua tagar besar, yaitu \#KLBBodong dan \#Moeldokosavedemokrat (Wijaya, 2021).

Kongres tersebut lantas mengajukan susunan kepengurusan dan Anggaran Dasar-Anggaran Rumah Tangga (AD-ART) versi tandingan ke Kementerian Hukum dan Hak Asasi Manusia (Kemenkumham) agar disahkan. Namun demikian, setelah mempertimbangkan demikian banyak hal, pada 31 Maret 2021, Menteri Hukum dan Hak Asasi Manusia (Menkumham) Yasonna Laoly, didampingi oleh Menteri Koordinator Politik Hukum dan Keamanan (Menko Polhukam) Mahfud MD, secara resmi menyampaikan bahwa kepengurusan Partai Demokrat KLB-DS tidak sah. Atau dengan kata lain, pemerintah memilih untuk tetap bertahan pada status quo nya. Yaitu hanya mengakui Partai Demokrat yang dipimpin AHY sebagai partai yang sah (Ainurrafik \& Indrianingrum, 2021).

Faksionalisme, sekali lagi, terbukti menjadi unsur penting yang memberi kerangka atas dinamika partai politik yang terjadi di Indonesia. Menggunakan rumusan masalah turunan, apa saja indikator faksionalisme, bagaimana faksionalisme dibentuk dan bagaimana faksionalisme mempengaruhi partai politik, penelitian ini berupaya untuk memperbarui posisi faksionalisme dalam topik kajian partai politik dan elektoral.

Adapun setidak-tidaknya 3 (tiga) kebaruan lantas ingin ditawarkan oleh penelitian ini. Pertama, bahwa ternyata, faksionalisme bisa diproduksi oleh aktor- 
aktor internal dan eksternal, meski awal mula konflik akan selalu berasal dari sumber internal. Situasi ini tentu memperbarui cara pandang tradisional yang masih meyakini internal sebagai satu-satunya aktor yang bisa memproduksi faksionalisme. Kedua, meski faksionalisme lekat dengan nuansa konfliktual yang merugikan, namun demikian, ternyata faksionalisme juga memproduksi keuntungan. Padahal, cara pandang lama masih mengedepankan faksionalisme yang hanya lekat dengan kerugian sebagai substansi. Ketiga, bahwa penyebab faksionalisme masih disorot secara lebih dominan dari sudut pandang konflik personal, bukan kegagalan institusional. Penelitian ini, oleh karenanya, meski baru secara implisit, justru ingin menyampaikan beberapa situasi yang menunjukkan bahwa institusi ikut bertanggung jawab terhadap munculnya faksionalisme.

Selanjutnya, faksi dan faksionalisme dalam penelitian ini akan digunakan dalam situasi yang berbeda. Faksi akan digunakan untuk menjelaskan kelompok aktor, sementara faksionalisme akan digunakan untuk menjelaskan proses yang terjadi pasca relasi kuasa-menguasai antar faksi terjadi. Adapun di dalam penjelasan mengenai kelompok aktor tersebut, penelitian ini akan membandingkan dinamika faksionalisme yang terjadi antara GanjarPDIP dan Partai Demokrat-KLB-DS. Ganjar akan lebih banyak dibicarakan sebagai individu, sementara PDIP akan dibicarakan satu paket dengan Puan sebagai organisasi. Sehingga sebagai sebuah diksi, PDIP dan Puan akan muncul secara bergantian. Sementara Partai Demokrat, AHY dan KLB-DS akan sama-sama dipandang sebagai unit organisasional. Meski demikian, Partai Demokrat-AHY dan KLBDS tetap akan dibaca sebagai kelompok terpisah.

Sebagai sebuah konsep, faksionalisme telah menjadi kerangka berpikir bagi banyak peristiwa. Baik bagi peristiwa yang terjadi di tingkat penyelenggaraan kekuasaan regional maupun lokal, maupun bagi peristiwa yang terjadi di periodisasi zaman kerajaan, penjajahan dan pasca-kemerdekaan. Dampaknya, faksionalisme telah menjadi topik penting bagi begitu banyak hasil penelitian.

Oleh karenanya, penelitian ini akan terlebih dulu menyajikan dua hasil penelitian yang telah dilakukan dalam konteks regional. Pertama misalnya, mengenai hasil penelitian yang dilakukan oleh Abidin (2020). Dengan mengambil Korea Utara sebagai fokus dan lokus sekaligus, penelitian tersebut berbicara tentang dinamika pembentukan negara yang ternyata disusun oleh praktik-praktik faksionalisme. Khususnya ketika, pada akhirnya, Korea Utara berhasil menyatukan faksi-faksi yang berkontestasi pada periode tersebut, yaitu faksi nasionalis Cho Man-shik, faksi sosialis Chinese Yenan dan faksi Manchurian (Abidin, 2020).
Kedua, hasil penelitian Dharmaputra (2011) yang berbicara tentang faksionalisme di dalam dinamika politik Rusia. Adapun meski tidak secara eksplisit membahas faksi, namun demikian penelitian tersebut tetap meletakkan pondasi faksionalisme pada momen-momen krusial. Termasuk ketika Dharmaputra mengutip pernyataan Bremmer dan Charap yang mengatakan bahwa utama sekali dalam periode kepemimpinan Putin, terjadi relasi kuasa-menguasai yang demikian erat antara tiga faksi, yaitu faksi liberal yang dipimpin Gref dan Kudrin, faksi teknokrat yang dipimpin Medvedev dan faksi Siloviki yang dipimpin Igor Sechin, Viktor Ivanov dan Nikolai Patrushev (Dharmaputra, 2011). Pada akhirnya, setidak-tidaknya melalui dua hasil penelitian tersebut, jadi diketahui bahwa di ranah regional, faksionalisme telah mendapat ruang analisis yang cukup.

Sementara di ranah lokal, pembahasan mengenai faksionalisme bisa dimulai dari hasil penelitian Octaviani (2020) yang menjelaskan tentang empat (4) faksi yang muncul di tengah-tengah masyarakat Aceh ketika harus menghadapi kolonialisme Belanda pada periode 1911-1942 (Octaviani, 2020). Juga, hasil penelitian Alit (2018) yang memposisikan faksi sebagai bagian yang tidak terpisahkan dari konflik politik Kerajaan Mengwi di Bali pada periode 18231871 (Alit, 2018). Sedangkan penelitian lainnya melihat bagaimana faksionalisasi dalam partai mengakibatkan perpecahan pengurus yang juga berdampak pada turunnya kekuatan partai (Djuyandi \& Suparman, 2020).

Adapun dalam kajian kepartaian yang terjadi di ranah lokal, faksionalisme juga bisa ditelusuri dari beberapa hasil penelitian yang sudah dilakukan. Misalnya melalui hasil penelitian berjudul Research Summary Political Party Factions and Internal Party Conflicts in Indonesia Under Reform Era yang dilakukan oleh Budiatri., dkk. (2017) yang berupaya untuk menyajikan faktor-faktor penyebab terjadinya faksionalisme secara spesifik. Di dalamnya, Budiatri et. al lantas melakukan kategorisasi atas penyebabpenyebab faksionalisme tersebut ke dalam dua kategori, yaitu internal dan eksternal. Menurut mereka, secara internal faksionalisme bisa disusun oleh ideologi, kompleksitas sosiologis, cairnya koalisi dan munculnya kepemimpinan yang elitisoligarkis. Adapun secara eksternal, faksionalisme bisa disusun oleh inefektivitas aturan hukum formal serta kombinasi teknis sistem pemilihan umum (pemilu); baik proporsional terbuka, multipartai ekstrim maupun langsung (Budiatri et.al., 2017). Selanjutnya, untuk mengerangkai penelitian tersebut secara lebih ilmiah, Budiatri et. al juga mengutip beberapa pengertian mengenai faksionalisme. Misalnya pengertian dari Zariski (1960), Rose (1964), Sartori 
(1976) serta Belloni dan Beller (1978). Budiatri et. al juga mengutip pemikiran Francoise Bucek tentang faksionalisme yang substansinya terletak pada “... dapat bertransformasi secara berulang" (Budiatri et.al., 2017).

Selain itu, faksionalisme juga sudah dikaji secara kasuistis oleh Firdaus Ali Firmansyah melalui hasil penelitiannya yang berjudul 'Wajah Faksionalisasi di Tubuh Partai Demokrat' (2015). Artikel tersebut menjelaskan secara empirik bahwa jika tidak dikelola dengan baik, faksionalisme berpotensi memproduksi konflik. Adapun tindakantindakan politik Partai Demokrat pada dan pasca kongres 2010 adalah objek dari penelitian tersebut. Hasilnya, alih-alih terkonsolidasi, faksionalisme justru tampil ke permukaan tidak lama setelah partai menuntaskan pemilihan ketua umum. Firmansyah, oleh karenanya, berpendapat bahwa salahsatu penyebab dari terjadinya situasi tersebut adalah relasi patron-klien yang masih berlangsung di dalam partai (Firmansyah, 2015).

Penelitian tersebut lantas sampai pada rekomendasi untuk mengidentifikasi, mengelola lalu menyelesaikan faksionalisme. Khususnya ketika Firmansyah mendorong agar teori penyelesaian faksionalisme dari Diamond \& Gunther (2001) dipraktikkan. Adapun teori penyelesaian faksionalisme Diamond dan Gunther sendiri memuat beberapa substansi sebagai berikut; mendorong dialog internal partai yang demokratis, merenungi prinsip-prinsip partai dan menyegerakan formalisasi prosedur penyelesaian sengketa partai (Firmansyah, 2015).

Faksionalisme sendiri merupakan kerangka berpikir penting bagi penelitian ini. Oleh karenanya, teorisasi faksionalisme Valdimer Orlando Key Junior (V.O. Key Jr.) dan Raphael Zariski (dalam Zariski, 1960) jadi relevan untuk digunakan. Adapun sebenarnya, konsepsi faksionalisme yang disampaikan oleh kedua ilmuwan tersebut tidak jauh berbeda. Jika V.O. Key Jr. berperan dalam menyusun dasar-dasar faksionalisme, Zariski-lah yang lantas mengembangkannya.

V.O. Key Jr. menyampaikan bahwa faksionalisme adalah ".. any combination, clique, or grouping of voters and political leaders who unite at a particular time in support of a candidate" (Zariski, 1960). Lalu Zariski menyajikannya secara lebih spesifik sebagai “... intra-party combination, clique, or grouping whose members share a sense of common identity and common purpose, and are organized to act collectively - as a distinct bloc within the party- to achieve their goals." (Zariski, 1960).

Penjelasan tersebut lantas menunjukkan bahwa faksionalisme mengalami penyempurnaan pengertian. Jika sebelumnya faksionalisme hanya dimengerti dalam konteks dasar berbasis'unity', saat ini, faksionalisme jadi bisa dimengerti dalam konteks yang lebih luas; yaitu juga dari tujuan, cara bekerja dan posisinya. Dampaknya, definisi faksionalisme jadi terdengar lebih operasional.

Adapun jika dikaitkan dengan relasi kuasamenguasai yang terjadi, faksionalisme akan menghasilkan tiga pengertian elaboratif sebagai berikut.Pertama, bahwa pada akhirnya, faksionalisme ingin memperoleh sedikit atau keseluruhan dari patronase atau kontrol. Kedua, bahwa faksionalisme akan senantiasa memperbarui kekuatan dengan melakukan konsolidasi secara kolektif di bawah hegemoni figur. Ketiga, faksionalisme muncul dari persoalan yang terjadi di dalam partai politik.

\section{METODE}

Sebagaimana diketahui bahwa pertanggung jawabanilmiah dari sebuah penelitian harus berangkat dari, setidak-tidaknya, dua cara dalam memandang realitas, yaitu non-positivistik dan positivistik. Nonpositivistik merupakan cara mengungkap realitas dengan meletakkan realitas itu sendiri sebagai bagian dari diri peneliti (Biyanto, 2015). Sebaliknya, positivistik merupakan cara mengungkap realitas yang mengakui eksistensi jarak antara realitas dan diri peneliti. Non-positivistik, dengan demikian, berkaitan erat dengan subjektivitas. Sementara positivistik justru terkait erat dengan objektivitas. Meski demikian, keduanya tetap bisa diakui sebagai kebenaran ilmiah.

Padahal, faksionalisme, yang menjadi ide penting bagi penelitian ini, merupakan fenomena politik yang memproduksi unsur subjektivitas dalam frekuensi yang lebih dominan daripada unsur-unsur objektivitas. Faksionalisme, sebagaimana diketahui, lebih dekat dengan sub topik mengenai klaim, konflik, power relation dan figur daripada perihal statistik, numerik atau algoritma. Oleh karenanya, merujuk pada situasi tersebut, penelitian ini jadi berkeperluan untuk menggunakan non-positivistik sebagai basis pengungkapan realitas.

Penelitian ini lantas ingin menggunakan studi kasus sebagai bagian dari metode penelitian kualitatif untuk menyajikan realitas faksionalisme ke ranah publik. Studi kasus, sebagaimana diketahui, merupakan studi turunan dari metode penelitian kualitatif, yang juga diturunkan dari cara berpikir non-positivistik sebagaimana penjelasan sebelumnya. Adapun sebagai metode teknis, studi kasus memiliki beberapa ciri elementer seperti terjadi dalam konteks kontemporer, melibatkan sumber data berlapis, meminta peneliti untuk melaporkan sebuah peristiwa secara deskriptif dan mendekati data dari semua sudut/komprehensif (Creswell, 2013). 
Lebih lanjut, Creswell, yang lantas dikutip oleh Sumarni juga mengatakan bahwa studi kasus fokus pada spesifikasi, kelompok budaya maupun potret kehidupan. Tak cukup sampai di situ, studi kasus juga disusun oleh kasus sebagai studi, kasusnya terikat dalam sistem yang memproduksi tempat dan waktu, sumber informasi berlimpah agar bisa merinci peristiwa yang terjadi dan perlu menggambarkan konteks sehingga membutuhkan waktu. Karakterkarakter tersebutlah yang lantas membedakan studi kasus dengan biografi, etnografi dan fenomenologi meski sama-sama berada dalam rumpun kualitatif (Yani, 2012).

Hanya saja, sebagaimana sudah disampaikan pada bagian sebelumnya, teknik pengambilan data dari penelitian ini dominan dilakukan dengan literature review. Oleh karenanya pernyataanpernyataan aktor yang terlibat, baik yang disampaikan secara resmi maupun tidak, yang lantas dikutip terutama oleh media online, adalah sumber data utama bagi literature review tersebut. Meski demikian, penelitian ini juga menggunakan data yang berangkat dari sumber lain, seperti informasi yang tertulis secara resmi melalui website organisasi dan materi yang diunggah oleh akun media sosial milik aktor-aktor terkait.

\section{HASIL DAN PEMBAHASAN}

\section{Indikator-Indikator Faksionalisme}

Bagian ini berperan untuk menganalisis praktik faksionalisme yang terjadi pada Ganjar-PDIP dan Partai Demokrat-KLB-DS dengan menggunakan indikator-indikator yang ditawarkan oleh Zariski. Atau dengan kata lain, bagian ini menjabarkan faksionalisme yang terjadi pada Ganjar-PDIP dan Partai Demokrat-KLB DS secara lebih operasional. Adapun secara teknis, indikator-indikator tersebut lantas terkontekstualisasi dalam tabel 1.

Penjelasan di atas lantas bermuara pada beberapa temuan. Pertama, bahwa ternyata faksionalisme akan selalu beririsan dengan dinamika internal partai terlebih dulu. Kedua, bahwa faksionalisme tetap tidak bisa dilepaskan dari patron-klien dan elitisme sebagai kata kunci penting. Apalagi karena setelahnya, faksionalisme akan memperkuat diri dengan mencari basis massa. Sehingga jelas bahwa situasi tersebut terkait dengan cara faksionalisme bekerja. Ketiga, bahwa ternyata, disain faksionalisme bisa muncul secara bervariasi. Adapun konsekuensi tersebut muncul dari relasi antar faktor yang terjadi di lapangan. Menariknya, pada gilirannya, disain tersebut bukan hanya akan menghasilkan kerugian bagi partai, melainkan juga keuntungan. Dengan demikian, menjadi semakin jelas bahwa besar/kecilnya pengaruh faksionalisme terhadap eksistensi partai akan sangat tergantung dari proses kemunculan, cara kerja dan dampaknya. Bagian selanjutnya adalah elaborasi dari tiga substansi besar tersebut.

\section{Kemunculan Faksionalisme}

Ganjarist, kelompok relawan yang lantas menunjukkan dukungannya secara terang-terangan kepada Ganjar untuk menjadi kandidat Presiden 2024 dari PDIP, seolah memberi konfirmasi bahwa Ganjar memang telah terlibat dalam berbagai upaya untuk menaikkan citra diri. Apalagi karena konferensi pers Ganjarist dilakukan pertama kali pada 1 Juni 2021, sebelas hari saja setelah insiden di mana Ganjar tidak diundang ke acara resmi PDIP terjadi (Amirullah, 2021). Meski demikian, tentu saja, Ganjar memilih untuk tidak menanggapi kemunculan kelompok relawan tersebut secara terbuka (Putri \& Wibowo, 2021).

Masalahnya, kemunculan kelompok-kelompok relawan yang mendukung kandidasi Ganjar pada Pilpres 2024 sebagaimana kemunculan Ganjarist tersebut semakin menunjukkan bahwa seolah-olah, Ganjar memang berkeperluan untuk merespon dukungan publik yang datang kepadanya. Akibatnya, PDIP murka. Apalagi karena faktanya, Puan, kandidat PDIP, selalu berada di bawah Ganjar dalam berbagai hasil survey yang telah diselenggarakan. Survey Puspoll Indonesia yang dilakukan pada

Tabel 1. Kontekstualisasi Indikator Faksionalisme

\begin{tabular}{|c|c|c|c|}
\hline Aspek & Deskripsi Menurut Teori Zariski & Ganjar-PDIP & Partai Demokrat dan KLB-DS \\
\hline Sumber Konflik & $\begin{array}{l}\text { Muncul dari dalam sebuah organisasi } \\
\text { (dalam hal ini partai/intra-party) }\end{array}$ & Keduanya muncul dari dalam partai. & $\begin{array}{l}\text { Keduanya muncul dari dalam partai. } \\
\text { Meski demikian, KLB-DS juga bisa } \\
\text { dianggap sebagai aktor dari luar partai } \\
\text { karena sudah dipecat. }\end{array}$ \\
\hline Cara Kerja & $\begin{array}{l}\text { Kolektif di bawah komando seorang/ } \\
\text { sekelompok figur }\end{array}$ & $\begin{array}{l}\text { Cara kerja "kolektif di bawah figur" } \\
\text { tersebut sudah terlihat dari faksi Puan. } \\
\text { Sebaliknya, belum terlihat dari faksi } \\
\text { Ganjar. }\end{array}$ & $\begin{array}{l}\text { Cara kerja "kolektif di bawah figur" } \\
\text { tersebut sudah terlihat dari faksi Partai } \\
\text { Demokrat. Sebaliknya, belum terlihat } \\
\text { dari faksi KLB-DS. }\end{array}$ \\
\hline Tujuan & $\begin{array}{l}\text { Meraih salahsatu, atau beberapa, } \\
\text { atau semua dari kondisi-kondisi } \\
\text { penguasaan berikut ini; patronase, } \\
\text { kontrol, atau pemenuhan } \\
\text { kepentingan kelompok }\end{array}$ & $\begin{array}{l}\text { Baru terlihat dari faksi Puan. } \\
\text { Sebaliknya, faksi Ganjar belum } \\
\text { menunjukkan upaya untuk mencapai } \\
\text { tujuan tersebut. }\end{array}$ & $\begin{array}{l}\text { Baru terlihat dari faksi Partai } \\
\text { Demokrat. Sebaliknya, faksi KLB-DS } \\
\text { belum menunjukkan upaya untuk } \\
\text { mencapai tujuan tersebut. }\end{array}$ \\
\hline
\end{tabular}


20-29 April 2021 misalnya, menunjukkan bahwa prosentase kepantasan Puan untuk menjadi Capres baru berkisar di 17,3\% saja. Jauh di bawah Ganjar yang telah mencapai 43,4\% (CNN Indonesia, 2021). Tentu, situasi tersebut lantas memproduksi dilema yang tidak sederhana bagi PDIP.

Lain halnya dengan apa yang dialami AHY. Saat itu, AHY yang baru satu tahun menjadi ketua umum Partai Demokrat, sudah ditekan oleh KLBDS untuk mundur dari jabatannya. KLB-DS sendiri, sebagaimana diketahui, merupakan kekuatan politik eksternal yang konsisten menggaungkan diskursus "anti dinasti politik" pada Partai Demokrat untuk menggulingkan AHY. Meski demikian, sebagaimana diketahui pula, KLB-DS diinisiasi oleh kader-kader yang, meski sekarang sudah dipecat, pernah bekerja militan untuk Partai Demokrat. Sehingga secara historis, sebetulnya KLB-DS tidak benar-benar bisa disebut mewakili ranah eksternal (Ramadhan \& Prabowo, 2021).

Pemecatan sendiri merupakan langkah formal yang, jika dirasa perlu, bisa saja diambil untuk menghukum kader yang melanggar Anggaran DasarAnggaran Rumah Tangga (AD-ART) partai. Adapun secara teknis, konflik tersebut mesti diselesaikan terlebih dulu oleh Mahkamah Partai sebagaimana amanat UU No 2 Tahun 2011 tentang Perubahan Atas Undang-Undang Nomor 2 Tahun 2008 tentang Partai Politik (Cahyani, 2019). Konsekuensinya, kader-kader yang telah dipecat tersebut akan lantas terkategori sebagai aktor eksternal partai. Padahal, sebagian besar inisiator KLB-DS yang dipecat tersebut merupakan tokoh-tokoh senior Partai Demokrat yang telah tuntas memahami tata kelola internal Partai Demokrat. Konflik Partai Demokrat, dengan demikian, telah menunjukkan salahsatu ciri kasuistis faksionalisme. Yaitu akan selalu muncul dari persoalan internal terlebih dulu, meski secara formal, aktornya sudah terkategori sebagai aktor eksternal.

Konflik Ganjar-PDIP dan Partai DemokratKLB DS tersebut lantas memperlihatkan bahwa faksionalisme bisa diproduksi oleh dua jenis aktor, yaitu internal dan eksternal. Meski demikian, sumber internal dan eksternal tersebut akan selalu beririsan dengan agenda-agenda internal terlebih dulu. PDIP misalnya, menunjukkan bahwa faksionalisme muncul dari saling berhadap-hadapannya kader internal partai. Sementara Partai Demokrat menunjukkan bahwa faksionalisme muncul dari berhadaphadapannya aktor internal dan eksternal partai.

\section{Cara Kerja Faksionalisme}

Faksionalisme akan selalu terlibat dalam relasi kuasa-menguasai. Faksi akan melakukan segala upaya untuk memperoleh massa yang bisa digunakan untuk memperkuat basis. Jika sudah kuat, faksi akan lebih dekat dengan tujuan penguasaan atas faksi lainnya. Bagian ini lantas berupaya untuk menyajikan cara faksi memperoleh massa, memperkuat diri lalu menguasai faksi lainnya tersebut. Pada akhirnya, sebagaimana tersaji pada tabel 1 , setiap faksi akan berupaya untuk sampai pada salahsatu dari kontrol, penguasaan atau pemenuhan kelompok.

Faktanya, akan sulit bagi Ganjar untuk memperoleh dukungan dari sesama kader PDIP. Situasi tersebut terjadi, utamanya karena Ganjar memahami bahwa PDIP, kemungkinan besar, akan mengajukan Puan untuk menjadi kandidat Presiden pada Pilpres 2024 mendatang. Prediksi tersebut lantas diperkuat oleh pernyataan dari tokohtokoh PDIP yang selama ini konsisten mendukung Puan. Utut Ardianto misalnya, seorang anggota PDIP senior, menyampaikan kembali pernyataan Bambang Wuryanto agar Ganjar mencari partai lain saja apabila benar ingin menjadi kandidat Presiden pada Pilpres 2024 mendatang (Indonesia, 2021b). Pendek kata, konsolidasi internal bukanlah metode yang bisa Ganjar pilih untuk memperkuat faksinya.

Oleh karenanya, Ganjar, sebagaimana ditekankan oleh Bambang Wuryanto, lantas memanfaatkan media sosial sebagai instrumen perjuangan alternatifnya. Apalagi karena faktanya, Ganjar memang termasuk ke dalam kelompok kepala daerah yang aktif menggunakan media sosial. Di twitter misalnya, Ganjar mengedepankan fungsi informasi, mendidik, hiburan, persuasi dan kontrol sosial (Harrera, 2016).

Tak hanya itu, Ganjar lantas memanfaatkan pencapaian di media sosialnya tersebut untuk memperlihatkan aktivitas dinas dan non-dinas sekaligus. Di instagram, aktivitas dinas disampaikan, salahsatunya melalui akun@lapak_ganjar yang bahkan dibuat terpisah dari akun pribadinya. Sementara aktivitas non-dinas banyak mendokumentasikan momenmomen di mana Ganjar sedang bercengkrama dengan masyarakat pada umumnya.

Adapun akun instagram pribadi lebih sering digunakan Ganjar untuk menyampaikan nilainilai kehidupan. Pada laman bio di akun Instagram miliknya misalnya, hingga penelitian ini usai disusun, tertulis "Tuanku ya Rakyat, Gubernur cuma Mandat" (Rahmah, 2020). Ringkasnya, meski Ganjar tidak pernah secara eksplisit menunjukkan aktivitas kandidasinya, namun demikian aktivitas-aktivitasnya di media sosial justru menunjukkan bahwa Ganjar sedang menyusun basis massa eksternalnya.

Sebaliknya, kemungkinan besar, Puan masih akan mengandalkan mesin partai untuk memperkuat faksinya. Hal yang terdengar wajar mengingat PDIP memiliki basis massa yang demikian militan. Bambang Wuryanto misalnya, dalam sebuah pernyataan bahkan sampai mengingatkan bahwa 
kemenangan Ganjar pada Pemilihan Gubernur (Pilgub) Jateng 2013 lalu juga terjadi karena kinerja partai. Sehingga wajar apabila PDIP ingin kembali menggunakan metode tersebut (Utomo, 2015). Oleh karenanya, menindak lanjuti rencana tersebut, strategi darat lantas dilakukan secara bertahap.

Namun demikian, cara memperkuat faksi yang dilakukan oleh Ganjar/PDIP tersebut berbeda dengan cara memperkuat faksi yang dilakukan oleh Partai Demokrat. Khususnya karena AHY sudah terlebih dulu menyampaikan kepada publik bahwa ada upaya pengambil alihan secara paksa dan illegal atas kepemimpinannya terhadap Partai Demokrat, bahkan ketika konflik tersebut belum muncul ke permukaan. AHY, dengan demikian, memilih untuk melemparkan pernyataan (mengenai konflik yang terjadi) ke publik terlebih dulu (Ainurrafik \& Indrianingrum, 2021). Oleh karenanya, entah diniatkan atau tidak, namun demikian keputusan tersebut tetap bisa dibaca sebagai strategi untuk mendongkrak elektabilitas.

Pada akhirnya, sebagaimana diketahui, baik faksi Partai Demokrat maupun KLB-DS, sama-sama memperoleh panggung nasional atas situasi yang terjadi. Bahkan, melalui popularitas yang sedang diraih tersebut, kedua faksi tampak mampu menekan Kemenkumham sebagai perwakilan Pemerintah agar berhati-hati menunjukkan keberpihakan. Semua upaya tersebut, dengan demikian, menunjukkan keinginan AHY untuk memperkuat faksi dengan mengoptimalkan jalur eksternal dan internal sekaligus.

Sedangkan KLB-DS tampak masih mengandalkan cara konvensional. Yaitu dengan menyelenggarakan KLB itu sendiri meski sebenarnya, ada strategi lain yang bisa digunakan. Tampaknya, untuk memperoleh basis massa, kelompok tersebut lebih percaya pada substansi daripada bentuk pergerakannya. Oleh karenanya, jika benar demikian, ketiadaan strategi mengenai bentuk pergerakan untuk merebut kekuasaan jadi terdengar wajar.

Tabel 2 berikut lantas menjadi visualisasi dari cara kerja masing-masing faksi untuk sampai pada tujuan politiknya. Adapun indikatornya bisa dilihat dari dua hal, yaitu cara mengumpulkan massa internal (pengurus, kader dan simpatisan) dan cara mengumpulkan massa eksternal (publik pada umumnya).

\section{Dampak Faksionalisme}

Konflik Ganjar-PDIP menunjukkan bahwa faksionalisme memiliki kemampuan untuk menghadaphadapkan sesama aktor internal. Sementara konflik Partai Demokrat-KLB-DS menunjukkan bahwa faksionalisme memiliki kemampuan untuk mempertemukan aktor internal dan eksternal sekaligus. Pada akhimya, konflik yang terjadi pada Ganjar-PDIP dan Partai Demokrat-KLB-DS akan memproduksi dampak. Namun demikian, ternyata, tetap ada dampak positif yang muncul untuk mengiringi dampak negatif faksionalisme. Bagian ini lantas ingin menjabarkan dampak negatif dan positif tersebut bagi masing-masing faksi. Dampak positif disebut keuntungan, sementara dampak negatif disebut kerugian.

\section{Untung-Rugi Ganjar}

Pertama, Ganjar jadi punya lebih banyak pendukung. Adapun secara teknis, mulanya, publik akan memposisikan Ganjar sebagai pihak yang didzolimi terlebih dahulu. Seolah-olah, suara masyarakat (meski baru melalui survey) yang menginginkan Ganjar untuk menjadi kandidat pada Pilpres 2024 mendatang, tidak bisa diakomodasi, atau bahkan berlawanan dengan suara PDIP yang menginginkan Puan. Padahal, pada akhirnya, masyarakatlah yang akan memilih, bukan PDIP. Simpati masyarakat tersebutlah yang lantas memunculkan beberapa organisasi relawan justru setelah polemik terjadi. Sahabat Ganjar yang dideklarasikan di Yogyakarta pada 20 Juni 2021 adalah contohnya (Indonesia, 2021a).

Kedua, karena sudah memiliki lebih banyak pendukung, Ganjar jadi punya pilihan tindakan politik yang lebih bervariasi. Apalagi karena Ganjar memiliki elektabilitas yang konsisten berada di lima besar penyelenggaraan survey. Situasi tersebut, tentu saja benar-benar menguntungkan Ganjar. Ganjar bisa tetap maju menjadi kandidat atau bisa memilih patuh pada PDIP meski tentu, setiap pilihan akan beriringan dengan resiko politiknya masing-masing.

Sementara kerugian Ganjar adalah akan semakin dijauhi PDIP. Apalagi jika mengingat bahwa PDIP-lah, melalui mesin partainya pada Pilgub 2013, yang mengorbitkan Ganjar hingga bisa menjadi tokoh nasional dan dikenal publik seperti hari ini.

Tabel 2. Cara Kerja Masing-Masing Faksi

\begin{tabular}{lll}
\hline \multicolumn{1}{c}{ Faksi } & \multicolumn{1}{c}{ Menguasai Basis Massa Internal } & Menguasai Basis Massa Eksternal \\
\hline Ganjar Pranowo & Tidak terlalu terlihat & Metode-metode digital \\
PDIP & Metode konvensional & Metode konvensional \\
Partai Demokrat & Konsolidasi internal & Mengikat perhatian publik melalui media \\
KLB-DS & Konsolidasi internal dimulai dari KLB & Mengikat perhatian publik melalui media \\
\hline
\end{tabular}


Faktanya, pada periode sekitar sebelum 2013 tersebut, Ganjar memang tidak lebih populer daripada namanama yang sudah mengemuka terlebih dulu seperti Don Murdono, Hadi Prabowo dan Rustriningsih (Utomo, 2015). Selain itu, Ganjar juga harus mempertimbangkan konstelasi politik intra-parlemen seandainya benar-benar terpilih menjadi Presiden tetapi dari partai lain. Yaitu ketika, bisa saja, PDIP, partai dengan anggota paling banyak di parlemen, berpotensi mengganjal kebijakan-kebijakan eksekutif Ganjar. Konstelasi politik intra-parlementer, dengan demikian, harus menjadi konsideran.

Kerugian lainnya adalah Ganjar justru bisa kembali menjadi 'bukan siapa-siapa' karena secara historis, suara di Jatenglah yang membuat dirinya populer. Jateng sendiri, sebagaimana diketahui, merupakan basis elektoral alamiah PDIP (Dian Purnama et al., 2013). Sehingga pada akhirnya, harus dipahami bahwa faksionalisme juga berpotensi memasukkan Ganjar ke dalam situasi politik resiko tinggi. Oleh karenanya, Ganjar benar-benar harus bertindak secara hati-hati jika tidak ingin kehilangan karir politik.

\section{Untung-Rugi PDIP/Puan}

Adapun faksionalisme akan memberikan setidak-tidaknya dua keuntungan sekaligus kepada PDIP. Pertama, partai jadi bisa memperoleh informasi mengenai gejala awal faksionalisme internal. Sehingga partai jadi bisa melakukan deteksi dini. Dengan melakukan deteksi dini, partai jadi bisa merumuskan langkah-langkah antisipasi yang pada akhirnya akan memperkuat sistem keorganisasian partai. Sistem sendiri merupakan penyesuaian istilah dari systemness, unit analisis yang berangkat dari persilangan aspek internal dan struktural sebagaimana disampaikan Vicky Randall dan Lars Svasand melalui teorisasi pelembagaan partai (Eristyawan, 2014).

Kedua, meski bersifat unintended, partai jadi bisa melihat bahwa suara Ganjar adalah suara masyarakat yang sebenarnya. Tentu, bolehboleh saja PDIP membentengi diri dengan hanya mengajukan Puan sebagai kandidat pada Pilpres 2024 mendatang. Namun demikian, faktanya, keputusan-keputusan politik elektoral selama ini banyak ditentukan di detik-detik terakhir/injury time pembahasan. Pada situasi krusial tersebut, boleh jadi Ganjar akan semakin dipertimbangkan. Selanjutnya jika opsi tersebut yang diambil, besar kemungkinan PDIP akan memenangkan dua pemilihan sekaligus, yaitu Pilpres dan Pemilihan Legislatif (Pileg). Apalagi karena, kegiatan memilih selalu diasumsikan berangkat secara otonom, meski terdiri dari pendekatan sosiologis, psikologis dan rasional (Wayan \& Suprapti, 2013).
Tetapi PDIP juga mengalami kerugian. Pertama, jadi terlihat bahwa ternyata, PDIP tidak berbeda dengan partai lainnya perihal pengelolaan konflik. PDIP, partai yang selama ini disebut-sebut sebagai partai solid, ternyata tetap saja mengalami konflik berlarut-larut. Bagi publik, situasi tersebut akan memunculkan turbulensi meski tidak signifikan. Adapun bagi internal partai, situasi tersebut lantas menantang kepemimpinan ketua umum PDIP, Megawati Soekarnoputri, untuk menjalankan tata kelola partai secara lebih teknis.

Kedua, potensi terjadinya pembilahan massa yang bisa saja terjadi mengingat pendukung Ganjar dan Puan sama-sama tidak bisa dianggap sepele. Jika tidak dikelola dengan baik, PDIP akan kehilangan suara secara signifikan. Apalagi mengingat bahwa konflik tersebut terjadi di Jateng, daerah yang menjadi basis alamiah PDIP di satu sisi, tetapi juga menjadi daerah di mana masyarakat didorong untuk merasakan hasil kerja Ganjar sebagai Gubernur secara langsung di sisi lainnya (Jateng, 2021).

\section{Untung Rugi Partai Demokrat}

Konflik faksional juga memproduksi keuntungan dan kerugian bagi Partai Demokrat. Keuntungan pertama misalnya, datang dari potensi terjadinya penambahan suara dalam berbagai survey, terutama karena 'framing' bahwa AHY sedang didzolimi. Faktanya, menurut survey yang dilakukan pada 23-28 Mei 2021 dengan melibatkan 1.200 responden melalui telepolling, suara untuk Partai Demokrat berubah menjadi $8,4 \%$ dari $7,77 \%$ pada 2019. Adi Prayitno, Direktur Eksekutif Parameter Politik Indonesia yang menyelenggarakan survey tersebut lantas mengatakan bahwa hasil tersebut erat hubungannya dengan konflik Partai Demokrat dan Moeldoko yang terjadi beberapa waktu sebelumnya (chri/has/arh, 2021).

Keuntungan kedua, Partai Demokrat jadi lebih konsolidatif (Ainurrafik \& Indrianingrum, 2021). Kerja-kerja politik Partai Demokrat di berbagai daerah terbukti jadi semakin solid karena mendapat tantangan dari kinerja politik kelompok KLBDS yang dipimpin Moeldoko. Konsolidasi lantas benar-benar menjadi kata kunci penting karena Demokrat masih tergolong sebagai partai yang berbasis personal, tetapi juga catch all (Aminuddin \& Ramadlan, 2015).

Sementara itu, kerugian Partai Demokrat yang pertama adalah potensi buruknya hubungan politik dengan Pemerintahan Joko Widodo. Hal tersebut bisa saja terjadi karena Partai Demokrat sempat menyampaikan dugaan keterlibatan menteri Jokowi dalam kudeta yang terjadi (Asmara, 2021). Meski akhirnya terbukti bahwa Moeldoko, anak buah Presiden Jokowi, memang terlibat, namun demikian, 
tidak ada bukti yang benar-benar menunjukkan keterlibatan Presiden Jokowi. Konsekuensinya, sebagaimana ditegaskan oleh Karyono Wibowo, Direktur Eksekutif Indonesia Public Institute (IPI), SBY sampai harus menyampaikan pidato khusus untuk memberi klarifikasi atas blunder tersebut (Rakhmatulloh, 2021).

Sedangkan kerugian Partai Demokrat yang kedua adalah dominasi SBY sebagai pemimpin strategis partai yang jadi semakin tampak meski hanya di balik layar (Prawira, 2021). Karena faktor SBY itu pulalah, tuduhan kelompok KLB-DS bahwa Demokrat dijalankan oleh dinasti Yudhoyono jadi terdengar logis. Oleh karenanya, jika tidak diantisipasi dengan baik, persoalan tersebut tentu akan menyulitkan perjuangan Partai Demokrat untuk memenangkan pemilihan umum (Pemilu) 2024 mendatang. Apalagi karena, sebagaimana diketahui, dinasti adalah isu yang mudah dimainkan untuk menjatuhkan lawan karena berkaitan erat dengan personalisasi partai yang banyak bermunculan pasca orde baru runtuh (Ekawati \& Sweinstani, 2020).

\section{Untung Rugi KLB-DS}

Faktanya, Partai Demokrat memang memiliki ketua umum berbasis pertalian keluarga. Dari yang sebelumnya dipimpin oleh SBY (ayah), lalu kini dipimpin oleh AHY (anak). Padahal, dinasti, bagaimanapun juga, adalah isu sensitif bagi diskursus demokrasikarenamembatasipartisipasipublik. Selain itu, politik dinasti juga meningkatkan kekhawatiran bahwa aspek kompetensi dalam proses pengisian jabatan publik akan dikalahkan oleh hubungan pertalian keluarga. Apalagi karena, dinasti berpotensi memproduksi kekuasaan menyimpang (Susanti, 2018). 'Tolak dinasti' lantas menjadi isu kolektif yang berusaha untuk dihilangkan dalam praktik demokrasi di Indonesia karena dianggap menghambat saluran politik secara umum (anti-demokrasi). Situasi jadi terdengar semakin runyam karena dalam konstelasi politik Indonesia secara umum, keluarga Yudhoyono cukup banyak menempatkan 'wakilnya'. Selain AHY, ada pula Edhie Baskoro Yudhoyono, Hartanto Edhie Wibowo, Agus Hermanto, Sartono Hutomo, Dwi Astuti Wulandari hingga Agung Budi Santosa (Gunanto, 2020).

Harus diakui, ketika KLB-DS muncul dan mulai diperbincangkan secara luas, tolak dinasti adalah isu kolektif yang jadi ikut diperbincangkan secara luas. Seolah-olah, KLB-DS mewakili lebih banyak entitas di luar faksionalisme yang terjadi, yang berkepentingan untuk menghilangkan eksistensi dinasti. KLB-DS, oleh karenanya, memperoleh perhatian publik karena berhasil melempar wacana "anti dinasti" tersebut kepada Partai Demokrat, salahsatu partai berpengaruh di Indonesia. Ini adalah keuntungan KLB-DS, yang mestinya bisa dimanfaatkan.

Namun demikian, di saat yang sama, KLBDS juga dicap sebagai pihak yang mencederai demokrasi. Anggapan tersebut muncul karena, alihalih dilakukan melalui cara-cara yang prosedural, proses pengambil alihan paksa kepemimpinan Partai Demokrat dari AHY justru dilakukan melalui pemaksaan penyelenggaraan KLB. Seolah-olah, semua cara bisa dilakukan untuk mengambil alih kekuasaan (Sukoyo, 2021). Anggapan tersebut tentu menjadi kerugian bagi KLB-DS.

\section{Faksionalisme Sebagai Isu Personal}

Hallain yang tidak kalah penting untukdianalisis adalah mengenai cara memandang faksionalisme. Faktanya, media, lantas memilih perseteruan antara Puan dan Ganjar, juga antara AHY dan Moeldoko, sebagai isu utama. Situasi ini menunjukkan bahwa, sampai pada batas tertentu, faksionalisme berbasis aktor justru dibicarakan secara lebih agresif daripada faksionalisme organisasional.

Di satu sisi, memang benar bahwa faksionalisme adalah konflik di mana faksi, sebagaimana disampaikan Zariski, akan selalu bekerja di bawah hegemoni aktor. Sehingga benar bahwa faksionalisme akan selalu mempertentangkan aktor. Namun demikian, aktor adalah bagian inheren dari partai politik sebagai sebuah institusi. Sehingga mestinya, faksionalisme juga dipandang sebagai hasil dari kegagalan partai dalam mengutuhkan institusionalisasi.

Media, oleh karenanya, berperan untuk menentukan bingkai dalam membaca faksionalisme. Seleksi isu lantas menjadi bagian yang tidak terpisahkan dari metodologi media dalam melakukan framing. Termasuk dengan menyajikan atau menyembunyikan isu-isu krusial (Astriani W, 2014). Adapun bagi faksionalisme, media memberi kontribusi dengan mengubah, atau minimal mengaburkan persepsi publik, dari yang sebetulnya bisa dibaca sebagai kegagalan institusional, menjadi hanya konflik personal antar aktor. Media, dengan demikian, juga merupakan bagian yang tidak terpisahkan dari narasi besar faksionalisme.

\section{SIMPULAN}

Penelitian ini, dengan demikian, sudah menjawab rumusan masalahnya. Melalui ulasan-ulasan kritis pada bagian pembahasan, muncul beberapa kesimpulan. Pertama, bahwa konflik yang terjadi antara Ganjar-PDIP dan Partai Demokrat-KLB-DS memang memenuhi syarat untuk disebut sebagai faksionalisme. Kedua, perbedaan keduanya terletak pada aktor pemicunya. Ganjar-PDIP mengakomodasi 
terjadinya faksionalisme yang dipicu oleh persoalan internal oleh aktor-aktor internal. Sementara Partai Demokrat-KLB-DS mengakomodasi terjadinya faksionalisme yang dimulai dari persoalan internal, tetapi dipicu oleh aktor eksternal. Ketiga, bahwa keduanya lantas memberi keuntungan dan kerugian baik bagi partai maupun aktor-aktor personal yang terlibat di dalamnya. Dan keempat, media adalah entitas yang ikut berperan dalam mengaburkan persoalan utama terjadinya faksionalisme, yaitu kegagalan institusional.

\section{DAFTAR PUSTAKA}

Abidin, N. F. (2020). Dinamika Politik, Heriofikasi KIM IL SUNG, dan Ideologi Juche di Korea Utara (1948-2011). Diakronika, 20(1), 61. https://doi.org/10.24036/diakronika/vol20iss $1 / 135$

Ainurrafik, F. K., \& Indrianingrum, A. P. (2021). Persepsi Hukum Indonesia Terhadap Kudeta Partai Politik. Lontar Merah, 4(1), 358-371.

Alit, D. M. (2018). Bara Agni di Kerajaan Mengwi (1823-1871). Social Studies, 06(2).

Aminuddin, M. F., \& Ramadlan, M. F. S. (2015). Match-All Party: Pragmatisme Politik dan Munculnya Spesies Baru Partai Politik di Indonesia Pasca Pemilu 2009. Jurnal Politik, 1(1). https://doi.org/10.7454/jp.v1i1.9

Amirullah. (2021). Pendukung Ganjar Pranowo Capres 2024 Deklarasikan Relawan Ganjarist. Tempo.Co.

Asmara, C. G. (2021). Geger AHY Tuding Menteri Jokowi Dukung Kudeta Partai Demokrat. CNBC Indonesia.

Assifa, F. (2021). Ganjar Tak Diundang di Acara Puan, di Rundown Tertulis "Kecuali Gubernur Ganjar.” Kompas.Com.

Astriani W, Y. A. (2014). ANALISIS BERITA PRA KLB PARTAI DEMOKRAT DI MEDIA VIVA.CO.ID DAN LIPUTAN6.COM. Jurnal Ilmu Komunikasi, 2(2), 1-13.

Biyanto, B. (2015). Positivisme dan Non-Positivisme dalam Jurisprudensi. Teosofi: Jurnal Tasawuf Dan Pemikiran Islam, 3(2), 483. https://doi. org/10.15642/teosofi.2013.3.2.483-502

Budiarti, A. P., Haris, S., Romli, L., Nuryanti, S., Nurhasim, M., Darmawan, D., \& Hanafi, R. I. (2017). RESEARCH SUMMARY POLITICAL PARTY FACTIONS AND INTERNAL PARTY CONFLICTS IN INDONESIA UNDER REFORM ERA. Jurnal Penelitian Politik, 14(2), 265-279.
Cahyani, V. D. (2019). PELANGGARAN KODE ETIK DAN AD/ART SEBAGAI PERBUATAN MELAWAN HUKUM DALAM PERSELISIHAN INTERNAL PARTAI POLITIK (STUDI PUTUSAN MAHKAMAH AGUNG NOMOR: $375 \mathrm{~K} /$ PDT.SUS-PARPOL/2017). Verstek Jurnal Hukum Acara, 8(3), 401-407.

chri/has/arh. (2021). Survei: Elektabilitas Demokrat Naik, Diduga Efek Moeldoko. Cnnindonesia. Com.

CNN Indonesia, T. (2021). Ganjar Pranowo Unggul dari Puan Maharani Versi Survei Puspoll. Cnnindonesia.Com.

Creswell, J. W. (2013). Qualitative Inquiry and Research Design Choosing Among Five Approaches - Third Edition. Sage.

Damhuri, E. (2021). Empat Lembaga Survei: 5 Tokoh Konsisten 5 Besar Capres 2024. Republika. Co.Id.

detikcom, tim. (2021). Moeldoko Via Telepon di KLB Demokrat: Saya Terima Jadi Ketum! Detik.Com.

Dharmaputra, R. (2011). Peran Identitas dalam Perubahan Sikap Rusia terkait Aksesi ke World Trade Organization. Global \& Strategis, Edisi Khusus, 237-250.

Diamond, L., \& Gunther, R. (2001). Political Parties and Democracy. The John Hopkins University Press.

Dian Purnama,A.A., Utomo, S., \& Martini, R. (2013). Strategi Politik PDIP Dalam Pemenangan Pasangan Ganjar - Heru di Pilgub Jawa Tengah Tahun 2013. Journal of Politic and Government Studies, 3(2), 266-275.

Dinilhaq, A. (2021). Ganjar Pranowo Ditendang PDIP No Problem, Banyak Partai yang Kepincut Usung Capres 2024. Wartaekonomi. Co.Id.

Djuyandi, Y., \& Suparman, S. M. (2020). Konflik Internal PPP Di Tengah Pilkada Jawa Barat 2018. Jurnal Civic Hukum, 5(2), 176-190. https://doi.org/10.22219/JCH.V5I2.13694

dmr/sur. (2021). Puan Maharani Sindir Pemimpin yang Cuma Ada di Medsos. CNN Indonesia.

Ekawati, E., \& Sweinstani, M. K. D. (2020). DAMPAK PERSONALISASI PARTAI TERHADAP DEMOKRASI INTERNAL PARTAI DI INDONESIA PASCA ORDE BARU. Jurnal Wacana Politik, 5(2), 111-123. 
Eristyawan, F. N. (2014). Pelembagaan Partai Kebangkitan Bangsa Studi Kasus Kemerosotan Suara Pada Pemilihan Umum Tahun 2009 di Jawa Timur. Journal Unair, 2-3.

Firmansyah, F. A. (2015). Wajah Faksionalisasi Ditubuh Partai Demokrat. Transformative, 1(1), 44-54.

Gunanto, D. (2020). Tinjauan Kritis Politik Dinasti di Indonesia. Sawala: Jurnal Administrasi Negara, 8(2), 177-191. https://doi. org/10.30656/sawala.v8i2.2844

Harrera, A. E. P. (2016). Pemanfaatan Media Sosial Twitter oleh Ridwan Kamil dan Ganjar Pranowo Telah Sesuai dengan Fungsi Utama Media Massa. Jurnal The Messenger, 8(2), 52. https://doi.org/10.26623/themessenger. v8i2.335

Indonesia, C. (2021a). Relawan Pendukung Ganjar Capres 2024 Deklarasi di Yogyakarta. Cnnindonesia.Com.

Indonesia, C. (2021b). Utut PDIP Persilakan Ganjar Maju Capres Lewat Partai Lain. Cnnindonesia.Com.

Jateng,A. D. (2021).Pelaku UMKM Jateng Didorong Manfaatkan "Lapak Ganjar." Portal Berita Pemerintah Provinsi Jawa Tengah.

Mustafa, H. (2011). Kepemimpinan Karismatik: Studi Tentang Kepemimpinan Karismatik Megawati Soekarnoputri Dalam PDIP Partai Demokrasi Indonesia Perjuangan. Universitas Islam Negeri Syarif Hidayatullah Jakarta.

Octaviani, H. (2020). Tipologi Masyarakat Aceh Pada Perang Aceh-Belanda 1873-1942.

Prasojo, M., Prakoso, L. Y., Mansyah, A., Hendra, A., \& Bangun, E. (2021). Pancasila as the Foundation of Political Ethics in Indonesia, Case Study of the Struggle for the Chairman of a Political Party in Indonesia. Journal of Social and Political Sciences, 4(2). https://doi. org/10.31014/aior.1991.04.02.280

Prawira, A. (2021). Politikus Demokrat: Tanpa Pak SBY, Tak Akan Eksis Partai Ini. Nasional. Sindonews.Com.

Putri, B. U., \& Wibowo, E. A. (2021). Enggan Komentar Soal Ganjarist, Ganjar Pranowo: Saya Konsentrasi Urus Jateng. Tempo.Co.
Rahmah, S. (2020). Personal Branding Ganjar Pranowo untuk Membangun Komunikasi Politik di Media Sosial Instagram. Jurnal Interaksi: Jurnal Ilmu Komunikasi, 5(1), 94-101. https://doi.org/10.30596/interaksi. v5i1.5584

Rakhmatulloh. (2021). Pernyataan SBY Dinilai Klarifikasi "Blunder AHY” yang Catut Nama Jokowi. Nasional.Sindonews.Com.

Ramadhan, A., \& Prabowo, D. (2021). Dipecat dari Demokrat, Jhoni Allen Akan Di-PAW dari $D P R$. Kompas.Com.

Sukoyo, Y. (2021). LP3ES: KLB Demokrat Refleksi dari Kemunduran Demokrasi. Beritasatu. Com.

Susanti, M. H. (2018). Dinasti Politik dalam Pilkada di Indonesia. Journal of Government and Civil Society, 1(2), 111. https://doi.org/10.31000/ jgcs.v1i2.440

Triutomo, A. (2020). Pola Kampanye Politik Puan Maharani Dalam Meraih Kursi DPR. https:// doi.org/10.31227/osf.io/nk35c

Utomo, S. (2015). PERAN PARTAI DEMOKRASI INDONESIA PERJUANGAN DALAM MEMENANGKAN PASANGAN GANJAR PRANOWO - HERU SUDJATMOKO PADA PILGUB JATENG 2013. Jurnal Ilmu Sosial, 14(2), 89-97.

Wayan, N., \& Suprapti, S. (2013). Pengaruh Sikap Dan Norma Subyektif Terhadap Niat Calon Pemilih Di Kota Denpasar Untuk Memilih Partai Demokrat Dalam Pemilu Legislatif Tahun 2014. Jurnal Manajemen, Strategi Bisnis Dan Kewirausahaan, 7(1), 29-39. https://doi.org/10.24843/MATRIK:JMBK

Wijaya, K. (2021). Konstruksi Berita Pada Media Online “"Beritasatu” Tentang Tagar \#Moeldokosavedemokrat Dan Dukungan Warganet: Analisis Framing Perspektif Zhongdang Pan-Gerald M Kosicki. Jurnal Ekonomi, Sosial \& Humaniora, 2(08), 13-19.

Yani, K. (2012). Studi Kasus. UGM Jurnal Edu UGM Press.

Zariski, R. (1960). Party Factions and Comparative Politics: Some Preliminary Observations. Midwest Journal of Political Science, 4(1), 27-53. https://doi.org/https://doi. org/10.2307/2108754 